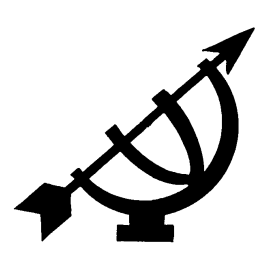

\title{
Die behuisingsbeplanning van informele nedersettings en plakkerskampe
}

\author{
Gerrit Pienaar \& Susan Bouillon \\ Fakulteit Regte \\ Potchefstroomse Universiteit vir $\mathrm{CHO}$ \\ POTCHEFSTROOM
}

Epos: pvrgjp@puknet.puk.ac.za

bouillon.susan@pretoria.gov.za

Abstract

The planning of housing for informal settlements and squatter camps

In South Africa approximately 7 million people live in informal settlements and squatter camps. Constitutional provisions and moral considerations necessitate the urgent involvement of different segments of society to alleviate the plight of this hapless part of the South African population. Since the early nineties the government's policy regarding squatters has changed from the criminalisation of squatting and the destruction of shelters to the acknowledgement of the right to access to adequate housing and the principle that an unlawful occupier may only be forcibly removed if alternative housing is available. This has led to a massive influx of squatters to squatter camps on the fringes of towns and cities. This article deals with the factors that lead to the establishment of informal settlements and squatter camps, the types of informal settlements and the way in which such settlements and squatter camps can be upgraded to become adequate housing. The consequences of self-help schemes and pirate urbanisation, and especially the advantages and disadvantages of such measures, are critically evaluated. The administration of housing in informal settlements by local authorities, the provision of basic services and the eventual upgrading of informal occupation to ownership are discussed. To facilitate this, the government policy regarding housing planning should be further implemented by removing practical obstacles as soon as possible.

\section{Agtergrond}

Informele nedersettings en plakkerskampe is ver verwyderd van die aanvanklike ideale vir behuising in die nuwe Suid-Afrika. Dit is egter duidelik dat dié nedersettings, wat landwyd sowat sewe miljoen mense huisves, nog lank 'n integrale deel van die land se behuisingsbeplanning 
gaan wees (Budlender, 1991:45-52; Van Eeden, 2000:1). Ingevolge konstitusionele voorskrifte ${ }^{1}$ en moreel-etiese oorwegings behoort daar op alle vlakke van die samelewing, en veral op juridiese, maatskaplike en ekonomiese terreine, aandag geskenk te word aan die lot van daklose persone en weerlose gesinne. Die volgende hofbeslissing sou inderdaad toegepas kon word op die breë situasie in die land:

People squat because they have to, not because they want to. The squatters are this country's people of conscience. Whatever their status in society may be or might have been, they are people who had been caught up in the exuberance of a new political dispensation which brought about drastic changes and instilled in them an exaggerated sense of freedom and security. The shortage of accommodation in urban areas forced them to live in shack towns or squatter camps on open land. Their plight should be recognised and should be treated with awareness and understanding. Humane action is needed, not a sledgehammer (Port Elizabeth Municipality v Peoples Dialogue on Land and Shelter 20002 SA 1074, p. 1079).

Die beleid van die vorige regering was tot en met die laat tagtigerjare een van afsonderlike behuisingsbeplanning vir verskillende rassegroepe, wat in die praktyk neergekom het op afsonderlike woongebiede en streng instromingsbeheer. ' $n$ Morele grondslag vir die afsonderlike beplanningsmaatreëls het grootliks ontbreek. Finansiering vir die behuisingsbeplanning en die infrastruktuur van wit woonbuurte het die gesamentlike toekenning aan ander rassegroepe ver oorskry (Witskrif op Behuising, 1994:3.1.5 en 3.3.6; kyk Suid-Afrika, 1994; Stevens \& Rule, 1999:107). Die wetgewing en prosedure waarmee instromingsbeheer vantevore toegepas is, het ingehou dat plakkershuise en -strukture genadeloos platgevee is. Plakkery is as gekriminaliseerde grondgebruik getipeer en deur middel van die Wet op die Voorkoming van Onregmatige Plakkery 52 van 1951 en die Groepsgebiedewet 36 van 1966 op 'n dikwels onmenslike wyse bekamp. Hierdie maatreëls was tot die beskikking van sowel plaaslike owerhede as individuele grondeienaars. Artikel 1(1) van die Wet op die Voorkoming van Onregmatige Plakkery 52 van 1951 het die onregmatige okkupasie of betreding van enige openbare of private eiendom sonder 'n wettige rede verbied. Indien 'n plaaslike owerheid of grondeienaar kon bewys dat 'n persoon 'n eiendom betree het, het die bewyslas op die laasgenoemde persoon gerus dat sodanige betreding op grond van 'n wettige rede geskied het (artikel 1(2)). Die oortreders kon 'n boete van R2 000 of tronkstraf van 12 maande op die lyf loop, terwyl artikel 3 die vernietiging van plakkershuise en informele strukture bepaal: "(1) Elkeen het die reg op toegang tot geskikte behuising." 
gemagtig het. Die beelde van stootskrapers wat plakkershuise platstoot en inwoners wat met oop vragmotors weggery is, sal die meeste SuidAfrikaners nog lank bybly (Van der Walt, 1992:40-55; Pienaar, 1999:12). In teenstelling met hierdie onmenslike soort handeling, word in Port Elizabeth Municipality v Peoples Dialogue on Land and Shelter 20002 SA 1074 op p. 1081 soos volg beslis:

The court, when having to decide a matter of this nature [naamlik uitsettings - GJP], would be obliged to break away from a purely legalistic approach and have regard to extraneous factors such as morality, fairness, social values and implications and any other circumstances which would necessitate bringing out an equitably principled judgment.

Die beleid wat tot in die tagtigerjare toegepas is, het die teenwoordigheid van swart mense in stedelike gebiede tot die rand van die stede en dorpe beperk in gebiede wat vir tydelike verblyf geoormerk was (Hindson \& McCarthy, 1994:29). Gedurende die vroeg-negentigerjare het simpatieke hofbeslissings egter toenemend bepaal dat uitsettings nie mag plaasvind indien geskikte alternatiewe verblyf nie vir die onwettige okkupeerders gevind kon word nie.2 Geboue en strukture kon nie meer deur die grondeienaar gesloop en vernietig word sonder 'n hofbevel nie. ${ }^{3}$ Ingevolge die nuwe behuisingsbeleid, wat veral neerslag gevind het in artikel 26 van die Grondwet van die Republiek van Suid-Afrika 108 van 1996 en die Behuisingswet 107 van 1997,4 het elke persoon 'n reg op toegang tot geskikte behuising. Dit het gelei tot die vervanging van die Wet op die Voorkoming van Onregmatige Plakkery 52 van 1951 deur die Wet op die Voorkoming van Onwettige Uitsetting en Onregmatige Besetting van Grond 19 van 1998. Hierdie Wet het 'n vasgestelde prosedure vir die uitsetting van onregmatige okkupeerders en maatreëls vir die hervestiging van onregmatige okkupeerdes ingestel (Pienaar, 1999:12-15). Hierdie ontwikkelings het daartoe gelei dat miljoene dakloses en plakkers uit die tradisionele tuislande en vanaf die platteland na stedelike gebiede gestroom het en hulle in plakkerskampe gevestig het. Die verslegtende arbeidsverhoudinge tussen (sommige) boere en hulle plaaswerkers, die toenemende afdanking van plaaswerkers om ekonomiese redes en

2 Diepsloot Residents' and Landowners' Association v Administrator of Transvaal 1994 4 SA 336 (A) 347-349; Executive Suite (Pty) Ltd v Pietermaritzburg-Msunduzi Transitional Council 19974 SA 695 (N) 710.

$3 \quad$ Mpisi v Trebble 19942 SA 136 (A); Rikhotso v Northcliff Ceramics (Pty) Ltd 19971 SA $526(\mathrm{~W})$.

4 Soos veral toegepas in Grootboom v Oostenberg Municipality and Others 20003 SA BCLR $227(\mathrm{KH})$. 
verskeie ander faktore het 'n groot rol in die toestroming na stedelike gebiede gespeel (Harrison, 1992:14-22).

Deur wetgewing is verskeie maatreëls ingestel om plakkers te vestig op persele in stedelike en plattelandse gebiede waar basiese dienste wel beskikbaar is. Die Wet op Minder Formele Dorpstigting 113 van 1991 en die Wet op Ontwikkelingsfasilitering 67 van 1995 bevat ingrypende maatreëls om grond vir die hervestiging van daklose persone en onregmatige okkupeerders te bekom, beskikbaar te stel en te ontwikkel. Tog kon daar nog steeds nie in die vraag na goedkoop en minder formele behuising voldoen word nie en is plakkerskampe rondom stede 'n realiteit waarmee nog vir dekades rekening gehou sal moet word. Die agterstand in behuisingsvoorsiening is gedurende 1995 op 1.5 miljoen eenhede beraam en daar is daarvoor voorsien dat dit jaarliks sal toeneem (Stevens \& Rule, 1999:107). Alhoewel daar sedertdien ongeveer 1.4 miljoen wooneenhede gebou is, is die agterstand in hierdie stadium nog feitlik net so hoog as in 1995 as gevolg van die toename in die aanvraag na formele behuising (South Africa, 2002). Dit noop mense om hulle tot informele behuising te wend.

Alhoewel bogenoemde beleid en ontwikkelings, wat in ooreenstemming met die kerndoelstellings van die Heropbou- en Ontwikkelingsprogram (HOP) is en neerslag vind in die Behuisingswet 107 van 1997, as moreel-etiese grondslag van behuisingsbeplanning lofwaardig is, is dit op grond van praktiese oorwegings en probleme steeds moeilik haalbaar. Die doel van hierdie artikel is om regsosiologiese aspekte van plakkerskampe en informele nedersettings wat buite die maatreëls van die Wet op Ontwikkelingsfasilitering 67 van 1995 en die Behuisingswet 107 van 1997 (wat hoofsaaklik oor formele behuisingsontwikkeling handel) bestaan, te ondersoek. Hierdie tipe behuising val gewoonlik buite die formele beplanningsektor en sal vanweë die gebrek aan 'n formele infrastruktuur in die toekoms al hoe groter eise aan behuisingsbeplanners stel. Kennis van die oorsake en omstandighede van hierdie informele verblyfvorme is noodsaaklik ten einde 'n beter begrip te kweek vir die huidige beleid, wat dikwels by gegoede huiseienaars tot groot weerstand aanleiding gee. Onderlinge begrip is noodsaaklik om die bestaande implementeringsprobleme van behuisingsbeplanning doeltreffend te ondervang. 


\section{Ontstaan en omvang van informele nedersettings en plakkerskampe}

\subsection{Omskrywing}

"Informele nedersettings" is voorheen omskryf as digbeboude woonbuurte vir gemeenskappe wat gehuisves word in selfgemaakte konstruksies onder informele of tradisionele verblyfsomstandighede (Hindson \& McCarthy, 1994:1). Tog vereis die konsep "informele nedersetting" herformulering. Hierdie konsep impliseer nie 'n geïsoleerde versameling mense met 'n unieke stel sosiale en ekonomiese verhoudings nie. Dit moet eerder gesien word as die gevolg van die informele vestigingspatroon in Suid-Afrika, waarin dit 'n belangrike funksie vervul (Kiepiel, 1994:129; Parnell, 1997:892-3). Hierdie woonbuurte word gevestig op grond wat wettig of onwettig beset is. In die eersgenoemde geval word dit 'n "informele nedersetting" genoem, terwyl dit in die geval van onwettige grondbesetting as 'n "plakkerskamp" getipeer word. Die "informeel" verwys na mense wat huise self bou, meestal sonder goedgekeurde bouplanne, in 'n gebied sonder formele stedelike beplanning en waar geen of net heel basiese dienste gelewer word (Van Eeden, 2000:1).

\subsection{Verstedeliking}

Die afskaffing van apartheid gedurende die negentigerjare het aanleiding gegee tot 'n komplekse proses van verskuiwing tussen landelike en stedelike gebiede en selfs binne stedelike gebiede. Dit het daartoe gelei dat geskikte grondstukke gesoek is om mense wat weens apartheidswetgewing toegang tot sekere gebiede geweier is, te vestig. Die natuurlike invloei na stede en dorpe het verder bygedra tot die bevolkingsgroei. Die groei in informele nedersettings en plakkerskampe in landelike gebiede het egter eweneens toegeneem, veral as gevolg van die groot getalle plaaswerkers wat plase vrywillig of gedwonge verlaat het. Dit is egter ' $n$ wêreldwye verskynsel dat die bevolking in stedelike gebiede vinniger groei as in landelike gebiede. Ook in Suid-Afrika blyk die verhuising van landelike na stedelike gebiede 'n hoofrede te wees vir stedelike groei (Hindson \& McCarthy, 1994:1; Stevens \& Rule, 1999: 107).

Dikwels word aangeneem dat net trekarbeiders deel van die plakkersgemeenskap vorm. Plakkers is egter nie net beperk tot nuwe aankomelinge in die stede nie, maar sluit ook mense in wat lankal reeds daar teenwoordig was en wat nie die beter kwaliteit behuising kon bekostig nie. Vestiging in plakkerskampe bied die inwoners relatiewe goeie 
toegang tot stedelike gebiede en selfbestuur teen 'n lae prys (Cross et al., 1994:95).

\subsection{Faktore wat gelei het tot die ontstaan van informele nedersettings en plakkerskampe}

'n Hoofoorsaak vir die ontstaan van informele behuising is behuisings- en akkommodasietekorte. Onvoldoende behuising word in stede en dorpe voorsien, en indien huise wel beskikbaar gestel word, is dit gewoonlik duur en onbekostigbaar. Dit het dus aanleiding gegee tot die ontstaan van oorbevolkte informele behuising in die stedelike gebiede.

Dit wil voorkom asof bekostigbaarheid en ligging die belangrikste twee faktore is waarmee rekening gehou moet word by informele behuising (Marais, 1997:173). Die gebiede wat vir vestiging uitgekies word, is gewoonlik op die rand van die stede en dorpe, sodat dit binne bereikbare afstande van die werksplekke af is. Die inwoners wil reiskoste verminder en formele behuisingskemas is dikwels ver van werksgeleenthede geleë (Gelderblom \& Kok, 1994:153-160; Parnell, 1997:896-897). Die ontstaan van plakkerkampe op die rand van stede was nog altyd 'n groot probleem. Weens die hoë konsentrasie van mense op een plek is die voorkoms van arm mense meer opmerklik in stedelike gebiede as in landelike gebiede, waar arm mense ook in groot getalle voorkom.

Bekendheid met die omgewing en/of die inwoners speel ook 'n rol by die ontstaan van informele behuising in en om bestaande stede en dorpe. Familie en kennisse wat in 'n stedelike gebied woon, help nuwelinge om 'n vastrapplek in die stad te kry (Stevens \& Rule, 1999:110). Plakkery op oop grond in en naby swart dorpsgebiede het in die middel van die tagtigerjare ontstaan weens die nie-kontrolering van dié soort ontwikkeling deur swart plaaslike owerhede en die nie-erkenning van die owerheid deur swart gemeenskappe. In die gebiede onder wit administratiewe beheer, daarenteen, het die ontstaan van plakkerskampe baie stadig plaasgevind en was dit beperk. Dit word toegeskryf aan die mag van wit plaaslike owerhede en hulle volgehoue weiering om plakkerskampe as wettig te aanvaar (Hindson \& McCarthy, 1994:25).

In Suid-Afrika het die konflik oor grond op baie maniere gemanifesteer, byvoorbeeld in geweld in plakkerskampe en konflik tussen die regering en gemeenskapsorganisasies weens die verskuiwing van plakkers. Baie redes kan aangevoer word vir die sensitiwiteit van die grondkwessie in Suid-Afrika. Hierdie faktore sluit in historiese faktore en die apartheidswetgewing tot 1991, wat onder meer die gedwonge vestiging en die skaarste aan grond vir swartes en gekleurdes ingehou het. Ingevolge die Ontwikkelingstrust en Grond Wet 18 van 1936 is byvoorbeeld slegs 13\% 
van die grondgebied in Suid-Afrika gereserveer vir swartes, wat op daardie stadium ongeveer $80 \%$ van die bevolking uitgemaak het (Van der Walt \& Pienaar, 1999:356). Regeringsbeleid het in die verlede op 'n hele aantal maniere ' $n$ belangrike rol gespeel in die strukturering en regulering van verstedeliking in Suid-Afrika. So byvoorbeeld het plakkerskampe hoofsaaklik ontstaan weens die vorige regering se apartheidsbeleid. Mense wat onwettig na die sogenaamde wit gebiede gestroom het en wat nie wettige behuising kon kry nie, het hulle op die rand van stedelike gebiede en dorpe tot plakkery gewend met die hoop op 'n beter lewe (Horn et al., 1992:113; Van Eeden, 2000:1).

\section{Tipes informele behuising}

Plakkery is 'n onwettige vorm van grondokkupasie, en kan slegs voortbestaan met die vergunning van die plaaslike owerheid of deur die mag van die plakkersgemeenskappe (met ander woorde die grootte van die gemeenskap). Daarbenewens word verskillende soorte informele nedersettings geïdentifiseer, veral op grond van die ligging daarvan. Informele nedersettings word aangetref op stamgrond, swart eiendomsgrond, in formele dorpsgebiede, op staatsgrond, op kleinhoewes en plaasgrond en aan die rand van stede en dorpe. Buiten bogemelde behuising is daar ook selfhelpskemas en skemas waarvolgens die bestaande nedersetting opgegradeer word (Harrison, 1992:14; Byerley \& McIntosh, 1994:145).

\subsection{Selfhelpskemas}

Selfhelpskemas het gedurende die sewentigerjare in die ontwikkelende lande aandag begin trek toe instansies soos die Wêreldbank dit as alternatiewe vorm van behuising vir lae-inkomstegroepe aangemoedig het. Plaaslike owerhede het grond in erwe verdeel, basiese dienste verskaf en grond vir ontwikkeling beskikbaar gestel, terwyl banke fondse voorsien het as boulenings. Persone sonder behuising moes aansoekvorms voltooi om vir die skemas te kwalifiseer. Gemeenskapsverenigings het die aansoeke bestudeer en toekennings gemaak. Lenings is aan die suksesvolle kandidate voorsien. Gesinne en uitgebreide gesinne het hulle eie huise gebou en dit met verloop van tyd verbeter en selfs vergroot (Pillay, 1994:46). Aan die begin van die tagtigerjare het hierdie situasie egter verander. Hulp met selfhelpskemas het begin afneem en banke het geweier om lenings toe te staan vir die opgradering van huise. Dit het ook geblyk dat die skemas net toeganklik is vir ekonomies selfstandige gesinne en dat die werklike arm mense nie daarin kon deel nie. Baie plaaslike owerhede was ook net bereid om erf- en diensteprojekte as 'n proefneming aan te pak. Dit was gewoonlik die meer gegoede inwoners wat die meeste voordeel uit hierdie skemas getrek het. In Suid-Afrika vorm selfhelpskemas 'n integrale deel van die 
beplanningsbeleid (Harrison, 1992:17-18). Daar moet egter rekening gehou word met die feit dat die privaatsektor slegs beperkte finansiering bied en dat slegs die inkomste-genererende huishoudings hierdeur baat.

\subsection{Opgradering van bestaande informele behuising}

In die verlede is plakkerskampe platgestoot en inwoners elders hervestig, maar die verskuiwing van mense en die verbrokkeling van gemeenskappe is baie nadeliger as gebrekkige huisvesting en woonomgewing. Die besef dat ligging en gemeenskapsbande belangrik is, het in die tagtigerjare en daarna gelei tot die opgradering van plakkersgebiede (Van Eeden, 2000:1).

Die opgradering van bestaande informele nedersettings het in SuidAfrika as selfhelpskemas begin vorm aanneem in die tagtiger- en negentigerjare. Die opgradering was gemik op die verskaffing van die belangrikste minimum-infrastruktuur by informele en soms onwettige, behuising. Opgradering het meestal gepaard gegaan met pogings om die inwoners se verblyfreg te verseker. Namate bestaande informele nedersettings wel opgegradeer en dienste en verblyfreg verseker is, is die huise en gehuggies stelselmatig opgegradeer (Stevens \& Rule, 1999: 110). Baie erf- en diensteprojekte en opgraderingsprojekte is gekombineer. Konsolidasie is gesien as 'n integrale deel van hierdie skemas. Ten opsigte van plakkery behels dit 'n proses waardeur verblyfregte gewettig en basiese dienste voorsien word. Dit het aanvanklik veral plaasgevind deur die Wet op die Afskaffing van Rasgebaseerde Grondreëlings 108 van 1991 en die Wet op die Opgradering van Grondbesitregte 112 van 1991, wat voorsiening gemaak het vir die omskakeling van huurpag en ander verblyfregte in eiendomsreg. Tans word dit gedoen deur die Wet op Ontwikkelingsfasilitering 67 van 1995.

Die opgradering van plakkerskampe gaan gewoonlik gepaard met die toewysing van grond aan die inwoners. 'n Probleem wat verband hou met die aanwysing van grond is die grootte van die erwe. Erwe kan nie te klein wees nie, aangesien plek vir uitbreiding gelaat moet word en erwe kan nie te groot wees nie, aangesien die beskikbaarheid van grond 'n probleem is. ' $n$ Verdere probleem is die bepaling van wie kwalifiseer om in die wettige en aangewese nedersettings te woon. Dit is dus belangrik dat gesinne wat woon in die gebied wat opgegradeer moet word, geregistreer word ten einde te bepaal wie kwalifiseer en wie nie (Gelderblom \& Kok, 1994:153-154; Stevens \& Rule, 1999:111).

Om plakkerskampe te verbeter is dikwels baie moeilik, omdat enige vorm van uitleg en dienste gewoonlik ontbreek. Selfs die vurigste ondersteuner van opgradering moet erken dat sommige plakkerskampe so sleg geleë 
is dat dit nie opgradeerbaar is nie. Dit is gewoonlik duurder as die uitlê van 'n nuwe behuisingskema (Van Eeden, 2000:1). Tog is daar voorbeelde van informele nedersettings, soos byvoorbeeld Lindelani in Kwazulu-Natal, of Eatonside en Etwatwa Extension 30 in Gauteng, wat so omvattend en goed geïntegreer is in die behuisingsisteem dat dit voor die hand liggend is dat dit sal bly voortbestaan en dus opgegradeer moet word (Boaden \& Taylor, 1992:149-152; Stevens \& Rule, 1999:110).

Net soos in die geval van selfhelpskemas het daar ook met die opgraderingsprogramme probleme ontstaan. Ook hier het die onvermoë om klein lenings vir huisverbeterings te bekom en die gebrek aan verblyfsekerheid dikwels die ontwikkelings in die wiele gery (Hindson \& McCarthy, 1994:33). Ontwikkelingsinisiatiewe ten opsigte van die meeste informele nedesettings het tot stilstand gekom in die onstabiele omstandighede van die laat tagtiger- en vroeg negentigerjare weens onopgeloste interne politieke probleme en opstande, of die aanvalle wat op buurgebiede uitgevoer is ten einde ontwikkelingsuksesse in die wiele te ry. Dit het tot gevolg gehad dat baie ontwikkelingsprojekte óf uitgestel óf gekanselleer is. As gevolg van die geweld is geboue wat beskadig is, nie herstel nie, minder dienste is gelewer en paaie is nie opgegradeer of herstel nie (Xaba, 1994:66-68). Met die inwerkingstelling van die Heropbou- en Ontwikkelingsprogram (HOP) in 1994 het dit noodsaaklik geword om geweld te stabiliseer. Pogings om probleme rondom informele behuising te hanteer, het gefokus op tegniese aangeleenthede soos die identifisering van persele en die verskaffing van basiese dienste. Min aandag is voor 1994 geskenk aan die sosiale en politieke probleme, met die gevolg dat die probleme bly voortbestaan het en dus tegniese oplossings bemoeilik het (Witskrif op Behuising, 1994:3.3.8; kyk Suid-Afrika, 1994; Marais, 1997:173-175; Stevens et al., 1998).

In die lig van bogenoemde probleme moet die opgradering van bestaande informele nedersettings eerder oorweeg word. Die behoefte wat bestaan om grond onwettig te beset, moet beperk word. Die beste manier om dit te doen, is om voldoende grond beskikbaar te stel vir informele nedersettings, veral in gebiede waar mense verkies om te woon. 'n Korttermyn-oplossing is die wettiging en opgradering van opgradeerbare plakkerskampe, soos wat gedoen is deur die Wet op die Opgradering van Grondbesitregte 112 van 1991 en die Wet op Herstel van Grondregte 22 van 1994. Langtermyn-oplossings kan gevind word in 'n kombinasie van die opgradering van informele nedersettings en die beskikbaarstelling van voldoende en geskikte grond vir informele behuising. So 'n stap sal die behoefte aan die besetting van grond verminder. Die opgradering van behuising en die beskikbaarstelling van grond word veral moontlik gemaak ingevolge die Wet op Minder Formele Dorpstigting 113 van 1991 en die Wet op Ontwikkelingsfasilitering 67 van 
1995. Op grond van die ooglopende voordeel van verblyfsekerheid verkies die huidige regering die skep van nuwe woongebiede en die opgradering van informele nedersettings bo die opgradering van plakkerskampe (Hindson \& McCarthy, 1994:27; Van Eeden, 2000:1).

\subsection{Pirate urbanisation: die voorbeeld van Bogota}

Plakkers is nie net in Suid-Afrika 'n probleem nie, maar ook in die meeste derdewêreldlande. Die omvang van informele behuising in derdewêreldlande word geïllustreer deur die feit dat plakkers dikwels meer as 'n kwart van die bevolking in groot stede uitmaak, en in sommige gevalle vorm plakkers die grootste deel van die bevolking. Dit lei tot verskillende oplossings om die behuisingsprobleem die hoof te bied. Een daarvan, wat veral die privaatsektor betrek, is pirate urbanisation.

'n Voorbeeld van pirate urbanisation word aangetref in Bogota, die hoofstad van Colombië. Die Verenigde Nasies het beraam dat die bevolking van Bogota in 2000 ongeveer 6,9 miljoen sal wees. Dit is 'n bevolkingsgroei van ongeveer 250000 mense per jaar, waarvan die helfte trekarbeiders is. Hierdie geweldige bevolkingsgroei in Bogota het veroorsaak dat ongeveer 70000 nuwe behuisingseenhede per jaar benodig word om almal te huisves. Die regering van Bogota was egter net in staat om ongeveer 15000 huise per jaar te bou, terwyl die oorblywende behuising (meer as $75 \%$ ) onwettig gebou is deur lae-inkomstegesinne wat nie kwalifiseer vir staatsbehuising nie. Ten spyte van hierdie onwettige oprigting van huise het grootskaalse besetting van grond nie in Bogota plaasgevind nie. Die wyse waarop die stedelike armes toegang tot grond verkry het, was deur ' $\mathrm{n}$ proses bekend as pirate urbanisation. Daar word beweer dat soveel as ongeveer $60 \%$ van Bogota se bevolking gewoon het in gebiede wat as gevolg van pirate urbanisation ontstaan het (Gelderblom \& Kok, 1994:221).

Pirate urbanisation (barrios piratos) verskil van gewone plakkery daarin dat grond van die eienaar gekoop word en nie net geneem of beset word nie. Ontwikkelaars koop landelike grondstukke wat aan die rand van stede geleë is. Hierdie grond word dan verdeel sonder om te voldoen aan die onderverdelingsregulasies of die standaarde vir dienstevoorsiening of soneringswette. Die toestemming van die plaaslike owerheid word ook nie verkry nie. Slegs die minimumdienste, soos byvoorbeeld geskraapte paaie en 'n paar wateraansluitingspunte vir die hele ontwikkeling word deur die ontwikkelaar aan die onderverdeelde erwe voorsien. Die onderverdeelde erwe word dan aan die behuisingloses verkoop. Hierdie kopers is meestal mense met 'n inkomste, maar wat nie genoeg verdien om formele behuising te bekostig nie. Hoewel die meeste van hierdie mense nie toegang tot krediet het nie, onderhandel 
die ontwikkelaar gewoonlik self met die koper oor betaalmetodes en die bedrag wat maandeliks gevorder sal word. Gewoonlik vereis die ontwikkelaars dat ongeveer die helfte van die koopsom as deposito aangebied word. Nadat die koopooreenkoms gesluit is, kan die koper enige soort huis van enige materiaal op sy erf oprig. Die regering van Bogota het in die verlede 'n hele aantal van die pirate urbanisation-ontwikkelings gewettig en sodoende is aan 'n groot deel van die bevolking toegang tot wettige openbare dienste en eiendomsreg verskaf.

Die belangrikste voordeel van pirate urbanisation is dat die ontwikkelaar die finansiering vir die aankoop van die grondstuk aan die koper verskaf, wat meebring dat die privaatsektor by hierdie vorm van behuisingsontwikkeling betrek word sonder die streng voorskrifte van die formele bank- en finansieringsektor. Pirate urbanisation het egter ook 'n paar voor die hand liggende, maar baie belangrike nadele. Gewoonlik word beplanningsregulasies oortree. Die grond word wettig bekom, maar die behuising word onwettig geadministreer deurdat dit nie deur die beplanningsowerhede gereguleer kan word nie. Daar is geen doeltreffende beheer oor stedelike groei nie. Diensverskaffingsagente kan dikwels as gevolg van die ligging van die grond nie bekostigbare dienste verskaf nie (Gelderblom \& Kok, 1994:221-223).

Tog moet besin word of pirate urbanisation nie in sekere gevalle 'n geskikte alternatief vir behuisingsbeplanning in Suid-Afrika bied nie. Pirate urbanisation kan in bepaalde omstandighede 'n goeie teenvoeter vir plakkery wees. In hierdie geval verkry 'n persoon gevestigde regte op 'n grondstuk, maar slegs minimale noodsaaklike dienste sal verskaf kan word. Grond hiervoor hoef nie noodwendig van privaat eienaars verkry te word nie, maar ongebruikte staatsgrond kan ook vir dié doel aangewend word. Dit blyk dat ongeveer 'n kwart (32 miljoen hektaar) van Suid-Afrika se grond in staatsbesit is. Groot stukke grond wat vir behuising geskik is, word tans nie gebruik nie en kan vir projekte soos pirate urbanisation aangewend word. Dit impliseer egter ' $n$ mate van samewerking tussen die openbare sektor en ontwikkelaars. Die grond sal teen 'n billike vergoeding deur die staat aan die ontwikkelaar beskikbaar gestel moet word, terwyl die ontwikkelingsproses deur privaat ontwikkelaars gehanteer word. 'n Soepeler benadering tot ontwikkeling en onderverdeling sal dus gevolg moet word.

\section{Administrasie van informele behuising}

\subsection{Administratiewe beheer}

Die eerste vereiste vir die bevordering van 'n volhoubare en werkbare vestigingsproses is die stabilisering van die hoë vlak van verhuising wat 
in informele behuisingsgebiede voorkom (Stevens \& Rule, 1999:110). Die tweede vereiste is om die verhouding tussen die informele behuisings- en stedelike beplanningsprosesse te bepaal (Cross et al., 1994:95). Die tipe administratiewe reëlings wat by informele nedersettings gevind word, is teoreties afhanklik van die de jure-eiendomsreg en beheer oor die grond en die administratiewe beheermaatreëls van die betrokke plaaslike owerheid. In die geval van plakkerskampe word dit beïnvloed deur die de facto-okkupasie en beheer van die grond sonder enige beheermaatreëls deur die plaaslike owerheid. Dit laat dus nou die vraag ontstaan wie beheer oor die plakkerskampe moet uitoefen met betrekking tot die verskaffing van dienste en die toepassing van wet en orde (Byerley \& Mclntosh, 1994:168-169).

\subsection{Sosio-ekonomiese aspekte van informele behuising}

\subsubsection{Behuising}

Daar bestaan 'n algemene wanopvatting dat alle informele behuising uit niks meer as vuil, onhigiëniese en bouvallige gehuggies bestaan nie. Die realiteit egter is dat daar ' $n$ wye verskeidenheid behuisingsoorte en -standaarde aangetref word, en dat dit verskil op grond van die strukture wat opgerig is, die duur van die bestaan en die omgewing wat dit skep vir sowel die inwoners en ander lede van die bevolking. Die behuisingstandaard verbeter dikwels met verloop van tyd, veral namate sekerheid van verblyfreg bekom word. Plakkershuise word mettertyd verander in soliede wooneenhede en later word druk op die owerhede geplaas om dienste soos water, elektrisiteit, riool, busvervoer, skole en gesondheidsentrums te voorsien. Vir die inwoners van hierdie nedersettings is vooruitgang stadig maar konstant. Huisgesinne wat 'n behoefte het om hulle woonhuise te vergroot kan dit doen, en daar is nie wetgewing waaraan voldoen moet word of bouplanne wat goedgekeur moet word nie (Gilbert, 1992:124-127).

\subsubsection{Vervoer}

Padtoestande is by informele behuising gewoonlik swak. Baie van hierdie woongebiede is so sleg geleë dat dit nie van 'n padnetwerk voorsien kan word nie. Busse en taxi's is die gewildste vervoermiddel, maar in die meeste gevalle het dit nie toegang tot die informele woongebiede nie. Hierdie verskynsel veroorsaak dat inwoners ver afstande na die bus- en taxi-staanplekke toe moet stap (Wilkins \& Hofmeyer, 1994:117). Namate die stede uitbrei, word die afstande na die werk ook groter. Hierdie faktor raak veral plakkers en armes wat op die rand van die stede woon en het 'n invloed op die finansies van 
huishoudings en die aantal ure wat tuis gespandeer word (Gelderblom \& Kok, 1994:100).

\subsection{Voorsiening van dienste aan informele behuisingsgebiede}

Plakkerskampe het gewoonlik geen toegang tot enige dienste nie. Huise word dikwels opgerig op persele wat nie geskik is vir diensverskaffing nie. Ook word die ligging van die informele behuising gereeld verander as gevolg van vloede, grondverskuiwings, of verhuising (Wilkins \& Hofmeyer, 1994:133; Cook, 1992:129) .

Die voorsiening van dienste vind baie stadig plaas, veral in vergelyking met die hoë vraag na dienste. Dit blyk dat die opgradering van dienste eerder by informele nedersettings as by plakkerskampe plaasvind. Die verskaffing van dienste aan informele nedersettings word egter dikwels beïnvloed deur die ligging van hierdie nedersettings. Ander faktore wat die verskaffing van dienste ook sal beïnvloed, is die digtheid van die informele nedersetting en die grootte van die gemeenskap. Baie van die informele nedersettings, veral op die platteland en in die tradisionele gebiede, is so geleë dat dit nie oor die infrastruktuur beskik om die voorsiening van dienste moontlik te maak nie. Veral die voorsiening van water en elektrisiteit is in hierdie gevalle besonder moeilik (May et al., 1994:135; Kiepiel, 1994:125).

In sommige informele nedersettings waar dienste wel voorsien is, is dit gedoen deur middel van wateraansluitingspunte ("standpipes") en vooruitbetaalde elektriese meters ("pre-paid meters"). Die koste verbonde aan die installering van hierdie vooruitbetaalde meters beloop in die omgewing van R3 500 tot R4 000 per meter. Die voordeel is egter dat geen uitgawes aangegaan hoef te word vir die bedrading van die huise nie. Die installering van die meters gaan ook nie gepaard met onrealistiese hoë veiligheids- en kwaliteitstandaarde nie, wat die installering in onder andere sinkhuise moontlik gemaak het. Die gebruiker kan die hoeveelheid elektrisiteit koop wat hy/sy kan bekostig en plaaslike owerhede het nie probleme met wanbetalings en begrotings nie (May et al., 1994:134-135). Wateraansluitingspunte, net soos vooruitbetaalde elektriese meters, is ook in sommige informele nedersettings geïnstalleer teen ongeveer R700 per aansluitingspunt. Vooruitbetaalde meters en wateraansluitingspunte het ' $n$ dramatiese verbetering in die potensiaal om dienste te verskaf teweeggebring (May et al., 1994:140-141).

Ten spyte van die afwesigheid van dienste in veral plakkerskampe, word daar tog wesenlike beleggings in sodanige vestigings gemaak. So byvoorbeeld maak mynmaatskappye beleggings in die vorm van klinieke wat opgerig en skole wat gebou word. Verdere beleggings deur die 
openbare sektor sluit onder andere in die beskikbaarstelling van geld vir die bou van opleidingsentrums of sportfasiliteite. Die oplossing is egter nie om ontwikkelingshulpbronne in die ontoeganklike woongebiede beskikbaar te stel nie, maar om dit te versprei na meer lewensvatbare, volhoubare en toeganklike liggings (Kiepiel, 1994:130; Hindson \& McCarthy, 1994:22).

\subsection{Opgradering na eiendomsreg of verblyfsekerheid}

'n Kritieke punt in die stabilisering van gemeenskappe hou verband met eiendomsreg of verblyfsekerheid. Stabiliteit verseker die kontinuïteit van ontwikkeling. In hierdie verband is veral die maatreëls van die Wet op Opgradering van Grondbesitregte 112 van 1991, die Wet op Herstel van Grondregte 22 van 1994, die Grondhervorming-Loodsprogram van 1995 en die Wet op Ontwikkelingsfasilitering 67 van 1995 van groot belang. Ingevolge artikel 62 van die laasgenoemde Wet kan voorlopige eiendomsreg toegeken word ten opsigte van persele wat in die proses van opmeting is en wat na opmeting en dorpsuitleg met die minimumkoste tot volledige eiendomsreg opgegradeer kan word (Bouillon, 1999:106-141). By plakkerskampe is grond egter dikwels nie opmeetbaar nie en skep dit die probleem dat die Wet nie hier toegepas kan word nie. Die de factokontrole oor grond en ander materiële hulpbronne is in hierdie geval van deurslaggewende belang. Die persoon wat grond beheer, beheer toegang tot residensiële ruimte en is in staat om surplusse in te vorder by wyse van huur, heffings en belastings. Beheer oor residensiële hulpbronne en infrastruktuur beteken ook beheer oor die sosiale verhoudings in 'n plaaslike gemeenskap (Morris \& Hindson, 1994:161).

Sekerheid van verblyfreg (en veral eiendomsreg) is vir die meeste plakkers belangrik en as dit nie realiseer nie sal hulle gewoonlik nie groot somme geld en tyd in huise belê nie - 'n situasie wat dikwels swakgeboude tydelike strukture tot gevolg het. Waar eiendomsreg of verblyfsekerheid nie bestaan nie, word huise so gebou dat dit maklik na ' $n$ ander perseel verskuif kan word. Waar grond onwettig beset word, is sekerheid van verblyfreg meer problematies, alhoewel die Wet op die Uitbreiding van Sekerheid van Verblyfreg 62 van 1997 en die Wet op die Voorkoming van Onwettige Uitsetting en Onregmatige Besetting van Grond 19 van 1998 tydelike beskerming teen die uitsetting aan plakkers verleen. Plakkers vestig meestal aan die rand van stede en soos stede groei, word hierdie grond vir stedelike ontwikkeling benodig. Ontwikkelingsgrond wat goed geleë is vir woondoeleindes word al hoe moeiliker bekombaar en meer mense word gedwing om grond te koop. Sodra grond blootgestel word aan die eiendomsmark, word die beskikbaarheid daarvan bepaal deur pryse. Grondpryse in derdewêreldlande is baie hoog as gevolg van spekulasie, dienste, sonering en die hoë koste 
van boumateriaal. Dit bemoeilik die verkryging van eiendomsgrond of formele behuising deur plakkers en lae-inkomstegesinne (Latsky, 1991: 55-58).

\section{Gevolgtrekkings en aanbevelings}

Informele behuising is 'n internasionale verskynsel. Die meeste wêreldstede word gekenmerk deur informele vestigingspatrone, veral tydens vinnige verstedeliking. Dit word veral veroorsaak deur ekonomiese groei, die persepsie van werksgeleenthede in stede en dorpe en die verarming van die platteland. In Suid-Afrika was die toepassing en afskaffing van apartheid 'n verdere katalisator in hierdie proses. Die probleem met ontwikkelende lande is die absolute armoede van mense wat verstedelik en die gebrek aan werksgeleenthede in die formele ekonomie. Dit beteken dat hierdie mense nie in die formele behuisingsmark opgeneem kan word nie (Van Eeden, 2000:1).

In die vroeë sestigerjare is aangeneem dat slegs die openbare sektor behuising wat veilig, netjies en higiënies is aan lae-inkomstegroepe kan verskaf. Ten spyte hiervan het die vestiging van informele behuising toegeneem, veral in ontwikkelende lande. Die algemene siening op daardie tydstip was dat informele behuising benede die nasionale standaarde was en dat dit gekriminaliseerde gebruik van grond meebring. Dit het gelei tot massaslopingsprogramme. Staatsbeleggings in konvensionele behuising is egter voortgesit. In Suid-Afrika was hierdie behuising egter oorwegend duur en armes kon dit gewoonlik nie bekostig nie (Pillay, 1994:45; Gilbert et al., 1997:133-147).

Dit is algemene kennis dat plakkery gepaard gaan met die onwettige besetting van grond. Dié probleem kan verklein word deur die beskikbaarstelling van meer grond vir informele nedersettings. Hoewel die nodige beleid en statutêre raamwerk hiervoor reeds geformuleer is, kan dit as gevolg van ' $n$ verskeidenheid van redes nog nie ten volle geïmplementeer word nie. Die groei in die getal mense in die plakkerskampe aan die rand van stede en dorpe het die skaarsheid aan residensiële hulpbronne soos grond, behuising en dienste beklemtoon, en het aanleiding gegee tot grootskaalse mededinging vir hierdie hulpbronne (Morris \& Hindson, 1994:158). 'n Oplossing is om reeds bestaande informele nedersettings vinniger op te gradeer as deel van laekostebehuisingskemas wat reeds deur plaaslike owerhede onderneem is. Deur basiese dienste soos strate en riolering te verskaf, sal die toestande in informele nedersettings aansienlik verbeter word. Die plaaslike owerheid kan verder as deel van die dienste voorafbetaalde wateraansluitingspunte en elektrisiteitsmeters goedkoop of kosteloos in dié gebiede installeer sodat meer mense toegang tot sodanige dienste verkry. Dienslewering kan 
gefinansier word uit 'n klein verhoging in die fooi vir die lewering van water en elektrisiteit aan persone wat alreeds toegang tot hierdie dienste het.

Deur meer geld te belê in die vestiging en opgradering van informele nedersettings kan die plakkersprobleem in Suid-Afrika doeltreffender aangepak word. Die geïntegreerde regeringsbeleid ten opsigte van behuising moet sigbaarder toegepas word deur behuisingsvoordele aan meer mense in die informele behuisingsektor te verskaf. In hierdie proses kan die privaatsektor betrek word deur ontwikkeling op staatsgrond deur plaaslike owerhede in vennootskap met ontwikkelaars te laat plaasvind (Witskrif op Behuising, 1994:5.7.6; vgl. Suid-Afrika, 1994). Dit kan geskied in 'n aangepaste vorm van pirate urbanisation deur die verslapping van die streng ontwikkelingsvoorskrifte in bepaalde omstandighede.

Dit is belangrik dat die regering die bestaande behuisingsbeleid sodanig sal toepas dat die behoefte aan grootskaalse stedelike uitbreiding so doeltreffend moontlik bevredig word. Die aanvaarding van die feit dat 'n groot gedeelte van stedelike groei informeel sal wees en die erkenning dat informele nedersettings 'n geskikte en volhoubare vorm van laeinkomstebehuising is, is alreeds 'n stap in die regte rigting. Bykomend hiertoe rus daar ook 'n morele verpligting op die privaatsektor (veral finansiële instellings en eiendomsontwikkelaars) om kreatief mee te werk tot die oplossing van die bestaande behuisingsprobleem.

\section{Bibliografie}

BOUILLON, S.G. 1999. Stedelike ruimtelike en grondontwikkeling in Suid-Afrika. Potchefstroom : PU vir CHO. (L.L.M.-verhandeling.)

BOADEN, B. \& TAYLOR, R. 1992. Informal settlement: theory versus practice in KwaZulu-Natal. (In Smith, D.M., ed. The apartheid city and beyond. London : Routledge. p. 147-157.)

BUDLENDER, G. 1991. Towards a right to housing. (In Van der Walt, A.J., ed. Land reform and the future of landownership in South Africa. Wetton : Juta. p. 45-52.)

BYERLEY, M. \& MCINTOSH, A. 1994. Administration of urban informal settlements. (In Hindson, D. \& McCarthy, J., eds. Here to stay: informal settlements in KwaZulu-Natal. Durban : Indicator Press. p. 167-176.)

COOK, G.P. 1992. Khayelitsha: new settlement forms in the Cape Peninsula. (In Smith, D.M., ed. The apartheid city and beyond. London : Routledge. p. 125-135.)

CROSS, C., BEKKER, S. \& CLARK, C. 1994. Migration into DFR informal settlements: an overview of trends. (In Hindson, D. \& McCarthy, J., eds. Here to stay: informal settlements in KwaZulu-Natal. Durban : Indicator Press. p. 83-98.)

GELDERBLOM, D. \& KOK, P. 1994. Urbanisation: South Africa's challenge. Pretoria : HSRC.

GILBERT, A. 1992. The housing of the urban poor. (In Gilbert, A. \& Gugler, J., eds. Cities, poverty and development. Oxford : Oxford University Press. p. 114-154.) 
GILBERT, A., MABIN, A., McCARTHY, M. \& WATSON, V. 1997. Low-income rental housing: Are South African cities different? Environment and Urbanization, 9: 133-147.

HARRISON, P. 1992. The policies and politics of informal settlement in South Africa: A historical perspective. Africa Insight, 22:14-22.

HINDSON, D. \& MCCARTHY, J. 1994. Defining and gauging the problem. (In Hindson, D. \& McCarthy, J., eds. Here to stay: Informal settlements in KwaZuluNatal. Durban : Indicator Press. p. 1-28.)

HORN, A., HATTINGH, P. \& VERMAAK, J. 1992. An urban interface settlement on the Pretoria metropolitan fringe. (In Smith. D.M., ed. The apartheid city and beyond. London : Routledge. p. 113-124.)

KIEPIEL, J. 1994. Settlement types and reconstruction. (In Hindson, D. \& McCarthy, J., eds. Here to stay: informal settlements in KwaZulu-Natal. Durban : Indicator Press. p. 123-132.)

LATSKY, J. 1991. The legal challenge of structuring housing finance for low income communities. (In Van der Walt, A.J., ed. Land reform and the future of landownership in South Africa. Wetton : Juta. p 53-67.)

MARAIS, L. 1997. Botshabelo's changing housing landscape. Africa Insight, 27:171177.

MAY, C., MAY, J., NEWTON, T., PERSAD, R. \& STRAVROU, A. 1994. Electricity and water provision. (In Hindson, D. \& McCarthy, J., eds. Here to stay: informal settlements in KwaZulu-Natal. Durban : Indicator Press. p. 133-142.)

MORRIS, M. \& HINDSON, D. 1994. Power relations. (In Hindson, D. \& McCarthy, J., eds. Here to stay: informal settlements in KwaZulu-Natal. Durban : Indicator Press. p 157-166.)

PARNELL, S. 1997. South African cities from the ivory tower of urban studies. Urban Studies, 34:891-906.

PIENAAR, G.J. 1999. The effect of the Prevention of Illegal Eviction from and Unlawful Occupation of Land Act 19 of 1998 on owners and unlawful occupiers of land. Property Law Digest, 3(2):12-15.

PILLAY, U. 1994. International perspectives on informal settlements. (In Hindson, D. \& McCarthy, J., eds. Here to stay: Informal settlements in KwaZulu-Natal. Durban : Indicator Press. p. 45-54.)

STEVENS, L., MARSHALL, S., MORRISON, M. \& RULE, S. 1998. Upgrading Gauteng's informal settlements. Vol. 3. Johannesburg : Community Agency for Social Enquiry.

STEVENS, L. \& RULE, S. 1999. Moving to informal settlement: The Gauteng experience. SA Geographical Journal, 81(3):107-118.

SOUTH AFRICA. 2002. Department of Housing. [Available on Internet:] http://www.housing.gov.za/. [Date of access: 29 April 2002].

SUID-AFRIKA. 1994. Witskrif op behuising. Staatskoerant 16178 van 23 Desember 1994. Pretoria : Staatsdrukker.

VAN DER WALT, A.J. 1992. Squatting and the right to shelter. Tydskrif vir SA Reg, 1:40-55.

VAN DER WALT, A.J. \& PIENAAR, G.J. 1999. Inleiding tot die sakereg. 3de uitg. Wetton : Juta.

VAN EEDEN, J. 2000. My pondok, my huis, my paleis. Rapport Perspektief:1, April 1.

WILKINS, N. \& HOFMEYER, J. 1994. Socio-economic aspects of informal settlements. (In Hindson, D. \& McCarthy, J., eds. Here to stay: informal settlements in KwaZulu-Natal. Durban : Indicator Press. p. 107-122.) 
XABA, T. 1994. Leaders in Lindilane. (In Hindson, D. \& McCarthy, J., eds. Here to stay: Informal settlements in KwaZulu-Natal. Durban : Indicator Press. p. 65-72.)

\section{Hofsake}

Diepsloot Residents' and Landowners' Association v Administrator Transvaal 19944 SA $336(A)$.

Executive Suite (Pty) Ltd v Pietermaritzburg-Msunduzi Transitional Council 19974 SA $695(\mathrm{~N})$.

Grootboom v Oostenberg Municipality and Others 20003 SA BCLR $227(\mathrm{KH})$.

Mpisi v Trebble 19942 SA 136 (A).

Port Elizabeth Municipality v Peoples Dialogue on Land and Shelter 20002 SA 1074 Rikhotso v Northcliff Ceramics (Pty) Ltd 19971 SA 526 (W).

\section{Wetgewing}

Behuisingswet 107 van 1997.

Groepsgebiedewet 36 van 1966.

Grondwet van die Republiek van Suid-Afrika Wet 108 van 1996.

Ontwikkelingstrust en Grond Wet 18 van 1936.

Wet op die Afskaffing van Rasgebaseerde Grondreëlings 108 van 1991.

Wet op die Opgradering van Grondbesitregte 112 van 1991.

Wet op die Voorkoming van Onregmatige Plakkery 52 van 1951.

Wet op die Voorkoming van Onwettige Uitsetting en Onregmatige Besetting van Grond 19 van 1998.

Wet op Herstel van Grondregte 22 van 1994.

Wet op Minder Formele Dorpstigting 113 van 1991.

Wet op Ontwikkelingsfasilitering 67 van 1995.

Wet op Uitbreiding van Sekerheid van Verblyfreg 62 van 1997.

\section{Kernbegrippe:}

behuising

beplanning

informele nedersettings

onregmatige okkupasie

plakkers

\section{Key concepts:}

housing

informal settlements

planning

squatters

unlawful occupation 